\title{
THE GOTHIC ELEMENTS IN TIM BURTON'S (1999) SLEEPY HOLLOW THE HEADLESS HORSEMAN: A LITERARY AND CINEMATIC ASPECT ANALYSIS
}

\section{Gerardus Majella Adhyanggono ${ }^{1}$ and Fransiska Linda Marcelina $^{2}$}

\begin{abstract}
Sleepy Hollow is a film directed by Tim Burton. The story tells about a young policeman Ichabod Crane, who is sent to a village called Sleepy Hollow to investigate a murder case there. At first, he was a person who never believed in supernatural things especially ghost, but after facing the reality of the ghost itself, he becomes very scared, but all he has to do is to find the villain behind the ghost of Headless Horseman. This thesis analyzes the gothic elements that are shown in this film. The theories that are used in this thesis are from film studies, literary and cinematic aspect. In this paper, the pictures from the scenes are also shown to show the evidence of the gothic elements. The theories that are used will also show how they can advocate the "gothicness" of this film.
\end{abstract}

Key words: cinematic, film, Gothic, literary

${ }^{1}$ G.M. Adhyanggono, S.S., M.A. <adhyanggono@yahoo.com> +62812256 71315 is a full-time lecturer at the English Department, Faculty of Letters, Soegijapranata Catholic University.

2 Fransiska Linda Marcellina, S.S. <lin2_chan@yahoo.co.id > +62818453900 is an alumnae from the English Department, Faculty of Letters, Soegijapranata Catholic University student. This paper is based on the thesis argument she defended for her Sarjana Sastra degree. 


\section{INTRODUCTION}

Nowadays, film has been popular among people of all ages. There are many kinds of films that have been created up until now. Many film directors compete to make good films. A film director is also called as an auteur if he or she is a complete film maker. Boggs and Petrie (2008:365) defines that the auteur is a person who gives the idea of the story, writes the script or screenplay, and then is involved in the film making process until the end of it. The style or characteristic of a film usually describes the director's personality himself. In this paper, the writer will analyze one of Tim Burton's movies because she is interested in this director's movie making.

Almost all of his movies contain dark and horror environment, so it is considered a Gothic movie. From all of Burton's movies, the writer chooses one of his films entitled Sleepy Hollow. This movie was directed by Tim Burton and it is an adaptation from the short story The Legend of Sleepy Hollow by Washington Irving. The story was set in 1799. It is about a young policeman Ichabod Crane who is sent from New York to the village of Sleepy Hollow to investigate the mystery of murders. Many villagers there say that the murders happen because the village is cursed by the headless horseman. After the head of a Hessian horseman is stolen, the horseman returns from hell to take the heads of the people of Sleepy Hollow until its own is returned. Through the investigation, Ichabod learns about the legend of the Headless Horseman, but he does not believe that the story is true because he believes only in logic. Yet, it is not for long until he sees with his own eyes when the horseman takes off one of the elders' head.

Many people accuse that the villain is Katrina; a daughter of Van Tassel, but Ichabod can unravel the murky plot by Katrina's stepmother Lady Van Tassel who controls the 
Horseman by taking the head skull to revenge on his family. After the fight in the local windmill, Ichabod can conquer Lady Van Tassel by returning the skull to the Horseman and makes him go back to the hell along with Lady Van Tassel. After his job is completed, Ichabod goes back to New York along with Katrina and young Masbeth. (Imdb 2012)

From the story above, it shows that Tim Burton has the characteristic of making the film in the sense that it contains dark and creepy situations with some ghostly things on it. This characteristic seems to meet some of the elements from Gothic Film that will be analyzed by the writer by using the literary and cinematic aspects. All of the elements like the setting that always takes place in an old castle; dark room, etc are basically taken from the gothic tradition which appeared in Horace Walpole's novel The Castle of Otronto because it has influenced the making of the gothic film up to the present day. With regards to the facts above, the writer decides to analyze the Gothic elements throughout the literary and cinematic aspect of Tim Burton's film "Sleepy Hollow".

\section{THE LITERARY ASPECTS IN FILM}

The elements in Gothic film are taken from the Gothic tradition in literature. Some of the elements of Gothic are based on the novel by Horace Walpole in 1764 The Castle of Otranto and it contains essentially all the elements that constitute the genre. Walpole's novel has influenced not only the Gothic novel, but also the gothic film making up until now. Harris (2008) explained that gothic elements include the following:

1. Setting in a castle Usually the action takes place in and around an old castle; sometimes it seems abandoned but 
sometimes occupied. But in the modern film making, the setting might be in an old house or mansion, darkness and shadows create the same sense of claustrophobia and entrapment.

2. An atmosphere of mystery and suspense

The work is pervaded by a threatening feeling, a fear enhanced by the unknown. Often the story itself is built around a mystery such as the unknown parentage, unknown events like murders.

3. An ancient prophecy

It is connected with the castle or its inhabitants (either former or present). The prophecy is usually obscure, partial, or confusing.

4. Omens, portents, visions

A character may have a disturbing dream vision, and in modern gothic fiction, a character might see something and think that it was a dream.

5. Supernatural or otherwise inexplicable events

To make the story more dramatic, amazing events occur, such as ghosts, giants walking or inanimate object coming to life. Sometimes, the events are ultimately given a natural explanation, while in others the events are truly supernatural.

6. High, even overwrought emotion

The characters are often in anger, sorrow, surprise, and especially terror. Characters suffer from nerves and feel like death to come. Crying and emotional speeches are frequent. 
Breathlessness, panic, and screaming are common

7. Women in distress

The female characters often face events that leave them fainting, terrified, screaming, or sobbing. A lonely, pensive, and heroine women that make them suffer because they are often abandoned, left alone, and have no protector at times.

8. The metonymy of gloom and horror

Metonymy is a subtype of metaphor, in which something like rain is used to stand for something else like sorrow. For example, the film industry likes to use metonymy as quick shorthand, so viewers can notice that it is raining in funeral scenes.

9. Villains

This character is usually cunning and shifty in their behaviour.

10. Protagonists

The Gothic heroes, usually they are burdened by the sorrow.

11. Romance

Usually the romance part will have the tragedy and sorrow line

(Buzzle, 2012).

In the literary aspect, the most common things to analyze a film are identifying the characterization, setting, point of view (POV), and symbol. 


\section{A. Characterization}

The first main character in Sleepy Hollow is Ichabod Crane. The writer assumes that he is a protagonist character which is included in one of gothic elements.

The second character is Katrina van Tassel. She is a powerful character who helps Ichabod in doing the investigation. Here, we can see that Katrina is a round character because at first, she is a lovely and charming girl, but then her character is changing from charming into heroine character. She can also be mentioned as the damsel in distress character because of her personality that makes the audience feel that this character is so lonely and full of suffers where the damsel in distress itself means about a woman character that often faces the events that make her being suffer (Harris 2008:П 8).

The third character is young Masbath. He is the son of Jonathan Masbath who has been murdered by the evil. This film shows that young Masbath helps Ichabod and accompanies him in his investigation after his father is murdered.

The fourth character is Lady Van Tassel. She is Katrina's step mother who is actually a villain behind the murder. She is able to perform spells that can control the horseman to kill the villagers in Sleepy Hollow. Here, the witch character is important in gothic film because it shows the atmosphere of mystery and magic which included in gothic elements. (Harris 2008: 3) From the explanation above, this type of character of Lady van Tassel can be identified as antagonist and flat character.

The last main character in this movie is the Headless Horseman or the Hessian. He is a ghost who is controlled by Lady Van Tassel to kill the villagers in Sleepy Hollow. The type of this character is antagonist and also flat character. He 
supports the main antagonist character by helping her to kill the villagers. This character embodies the elements of supernatural power which often appears in gothic film. The following is a sample of using close-up technique:

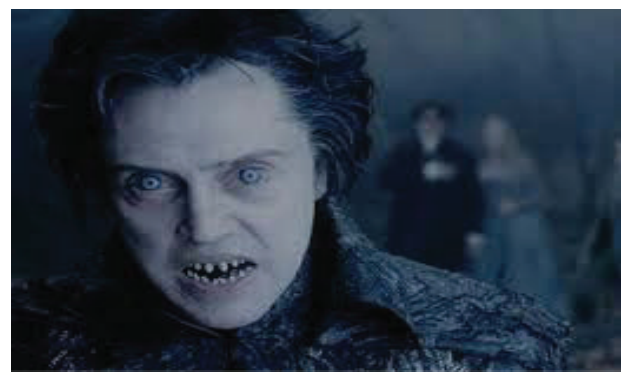

Picture 1

\section{B. Setting}

In this film of Sleepy Hollow, the setting sets in New York in 1799. The place of the setting fulfills the gothic element which is almost always in the dark place and gloomy situation, because most of the scenes are always set in the forest and old houses. Like when Ichabod comes to the village for the first time, where many old houses and darkness situation are all shown. It can prove that from the setting of the film, the gothic elements are shown. The foggy and stormy weather in this film also point out the gothic elements

\section{Point of View}

This film is using the first point of view because it brings the audience into the film so that they can feel that they are the character and they know what the characters feel in the creepy situation. 


\section{Symbol}

In gothic films, the audience will often see and find some symbols in them. Why? It is because gothic itself has many symbols that each of them has a specific meaning related to the supernatural or magical things and make it advocates the "gothicness" in a gothic film. The first symbol of the film is blood. It is an important symbol that often used in gothic films because it has a specific meaning. The scene that shows about this symbol can be seen when Ichabod meets a fortune-teller to ask about the Headless Horseman's place.

\section{The Fortune-teller : He rides to the Hollow and back. I hear him. I smell the blood on him. \\ Ichabod : Do you? Well, I'm here to find him and make him stop.}

From the statement, the gothic element of an atmosphere of mystery and suspense is shown. Another gothic element is about the prophecy from the fortune-teller statement, "I smell the blood on him" (show the minutes/ hours) means that the Horseman will come back to kill another victims even though he has been dead. It is like Harris (2008) said that the prophecy is usually obscure, partial, and even confusing.

The second symbol found is a tree. It is often identified as an important symbol in gothic films. It is because from the earliest times trees have been the focus of religious life for many people and they think that it is a sacred thing to be worshipped because they believe that tree is a gate of heaven that makes the dead person to be returned to the womb of the mother tree goddess. (Christopher 1998) In this film, this tree is called as the Tree of The Dead. It becomes a gate for the 
Headless Horseman to come out from his world to kill the villagers in Sleepy Hollow.

The last symbol is the evil eye. It is drawn by Katrina to protect Ichabod against evil spirit. It appears when she draws the symbol on the church floor. It can be proof that there is a kind of supernatural things in this film. In general, the picture that Katrina draws is called a penstagram and it is used for protection and to banish energy depends on how it is drawn.

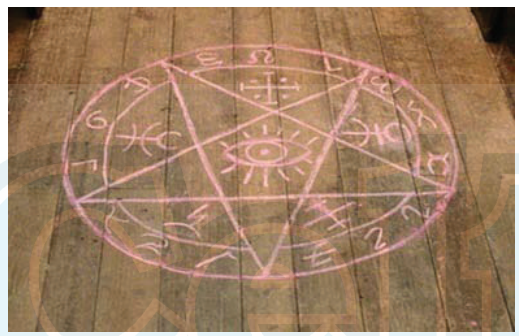

Picture 2

The picture above, the penstagram is drawn with five-point stars pointed up, to show that it makes the protection against the evil spirit. That is why Katrina draws this symbol to protect her beloved one, Ichabod, but when he sees this penstagram upside down like the picture above, the five-pointed stars pointed down. If the star pointed down, it will represent the dark side and also a symbol of evil. This is why after seeing this upside down penstagram Ichabod thinks that Katrina is the villain because she draws this kind of symbol to call the Headless Horseman.

\section{THE CINEMATIC ASPECTS IN FILM}

In this part, the writer discusses about the cinematic aspects in Gothic Film based on the movie Sleepy Hollow. 
These aspects will help the writer to analyze the gothic elements from this film. In a gothic film the use of cinematic aspects are very important to show and advocate the "gothicness" of it.

\section{A. Cinematic Point of View}

In this film, the cinematic point of view that is often used is the indirect-subjective point of view because the camera movement often used close-up shot. There is a scene when Ichabod sees the fake Headless Horseman who is actually the villagers who want to scare him. In this scene the camera takes a close-up shot to show the fear and surprised expressions of Ichabod.

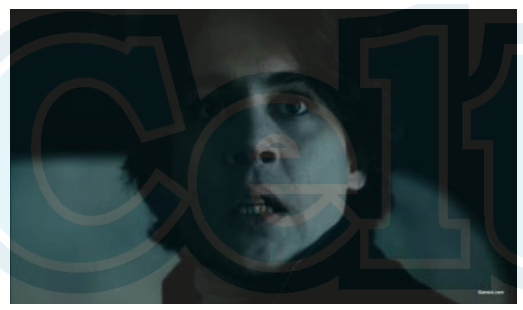

Picture 3

This scene also contains gothic element which is high, even overwrought emotion that in this case, we can see Ichabod's emotion like surprise, fear, nervous, and feel like death to come.

\section{B. Elements of Cinematic Compositions}

The first technique of the size and the closeness to the object from this film support the gothic element that shows the atmosphere of mystery and suspense. It is shown in the scene in the beginning of the film when a man who is on the way to send a letter to Sleepy Hollow. In the middle of his travel, he 
feels like there is someone following him. Here the camera is looking closer to the man, so that the audience can feel the feeling of the man who is being scared at that time.

The sharpness focused on the object is also shown in the film. In the scene when Ichabod finds a corpse in the river, the camera shoots to the object of Ichabod and the other objects are blurred. Its purpose is to make the audience stay focus to Ichabod only. From this scene the gothic elements are conveyed in the situation from the picture which shows the dark atmosphere and the panic looking character.

The use of the lighting set in this film is very determining to convey the gothic elements. Most of the scenes in this film use the low key lighting that make the whole scene of it becomes darker and builds the gloomy atmosphere in every setting in this movie. But, there are scenes that use the high key lighting. It is used when it comes to the Ichabod's vision of his dream.

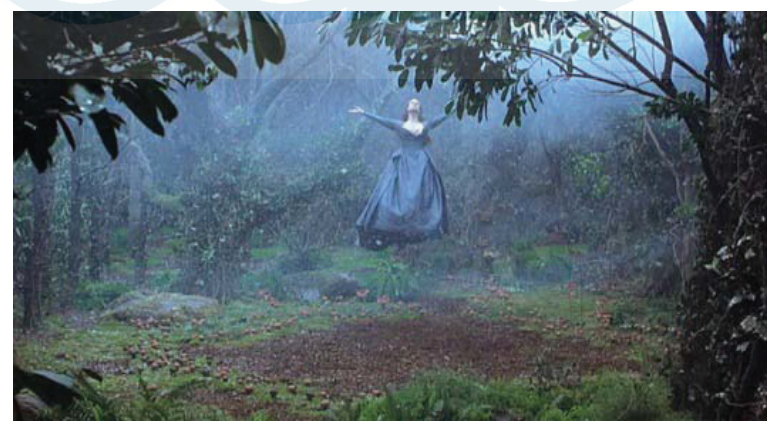

Picture 4

The gothic element of a vision is seen in this part when Ichabod is dreaming, and also the supernatural when his mother is flying in the air. 


\section{Specialized Cinematic Technique}

Some specialized cinematic techniques are also used in this film. Like the first technique of the extreme close-up shot that is shown in the scene when Ichabod is told about the story of how the horseman was killed and the camera shoot in Ichabod's hands that are holding a glass tremble because it can tell the audience that Ichabod is so scared when he heard the story. The audience will think that Ichabod is a coward and it also show that he is a protagonist character which is included in the gothic elements.

The second technique is close up. It is used when a man who is running away from the Hessian (Headless Horseman) and he is trapped in the corn field with a terrified expression showed on his face. By taking this shot, the gothic elements of the atmosphere of mystery is shown from the murder event. With this technique, the gothic element such as high, even overwrought emotion is also shown from the character's expression like fear, surprised, and terror. The headless horseman here can be categorized as the omen that is included in gothic element, and the next gothic element that is shown is the supernatural or otherwise inexplicable events from the appearance of the Headless Horseman.

Another technique is Dutch tilt, it shows in the scene when Ichabod meets the Headless Horseman and sees him killing the Magistrate in front of him. This shot makes the audience to see the surprised expression of Ichabod when he sees a ghost for the first time and realized that Headless Horseman really exists. The feeling of tense can be more shown with the bad weather with the light of the thunder makes the situation become creepier. The atmosphere of mystery and suspense is also seen from the murder scene of the Magistrate. 
An extreme long shot is used in the scene when the first time Ichabod arrived in Sleepy Hollow. The camera shoots on the setting of the village from far away and make the audience know that this village of Sleepy Hollow is so scary and gloomy with the graves inside it, the old houses, and the weather that is always cold and foggy.

The medium shot is shown in the scene when Ichabod is going back to his home and he suddenly feels that there is someone following him. At this time, the audience will feel that something is going to happen to Ichabod. From this scene the atmosphere of mystery and suspense and the elements of high, even overwrought emotion like scared and terror are all shown. Here, the metonymy of gloom and horror is also shown when Ichabod heard the horse footsteps approaching where actually the one who is following Ichabod is a fake Headless Horseman to scare him.

The technique of panning is also used in the scene when Ichabod and Brom are running away from the Headless Horseman. In this technique, the camera shots from right to the left to show the gothic elements of the atmosphere of mystery and suspense, because the characters feel like they are going to be killed by the Headless Horseman, so they are running away from him. The gothic element of high, even overwrought emotion is also shown from the character's expression like scared, panic, and feel like death to come.

Besides, the low angle is used in the scene when Katrina is trapped by her mother in law Lady Van Tassel. Here the camera shoots Lady van Tassel from below to show the powerful, the superior, and the madness of the villain. This scene also shows the atmosphere of mystery and suspense when the villain is going to kill the victim. 
Another angle shot like high angle shot is also used in the same scene when Katrina is going to be killed by her mother in law Lady Van Tassel. Here the camera takes closer from high angle to show the gothic element of woman in distress of Katrina as the victim, and a character that is being suffered because she knows that she is going to be killed by the Headless Horseman. This camera technique can also show her expression of the fearfulness and panic in that situation, and also the powerlessness of the victim.

\section{CONCLUSION}

From the analysis, the writer can find the gothic elements from this film by the literary aspect like characterization, point of view, setting, and symbol. Most of the characterization in this film is protagonist, and others are the antagonist or in the gothic elements we call it as the villain. From the setting, the gothic elements that can be found are dark and gloomy setting such as forest, and old houses with foggy and stormy weather. The symbol is also related to the supernatural or magical things, for example the Tree of the Dead which means very sacred and as a gate to the heaven to make the dead people go back to the womb of Goddess.

The second theory is from the cinematic aspect such as the cinematic point of view, elements of cinematic composition, and the cinematic technique. In the cinematic point of view, the writer found that this film is using indirectsubjective camera to show the gothic elements of fear, surprised expression, nervous and feel like death to come. The using of cinematic composition here also advocates the gothic elements. For example, the use of low key lighting can show the darkness and gloomy setting of this film. In conclusion, this 
GM Adhyanggono and FL Marcelin, Gothic Elements in Sleepy Hollow253

film of Sleepy Hollow contains many gothic elements. These are proven by using the theories that the writer used, literary and cinematic aspects that also advocate the "gothicness" of this film.

\section{REFERENCES}

Ben, Andec. "Filmography of Tim Burton". Retrieved from http://sensesofcinema.com/2003/great-directors/ burton/, 24 June 2012

Boggs. J. M. and D. M. Petrie. The art of watching films, $7^{\text {th }}$ ed., Mountain View, California: Mayfield Publishing Company, 2008.

Brown. T. J. MR (Marketing Research). United States of America, 2012.

Buzzle. "Elements of Gothic literature". Retrieved from http://www.buzzle.com/articles/Gothic-literature.html, $\quad 25$ June 2012.

Harris, R. "Elements of the gothic novel". Retrieved from http://www.virtualsalt.com/gothic.htm, 2008; 6 June 2013,

Hill, J. and G. Pamela. The Oxford Guide to Film Studies, $2^{\text {nd }}$ ed., England: University of Oxford, 1998.

Imdb "Synopsis for sleepy hollow". Retrieved from http://www. imdb.com/title/tt0162661/ synopsis, 21 November 2012.

Jerrold. E. H. Cambridge Companion to Gothic Fiction. Cambridge University Press. Eds., 2002.

Kaye, H. A Companion to the Gothic. Edited by David Punter. Oxford: Blackwell Publishing Company, 2001. 
Laurence. P. Literature: Structure, Sound, and Sense. Harcourt Brace College Publishers, 1979.

Lewdon, L. "Twin Peaks and the Television Gothic." In Literature/Film Quarterly, 1993.

Morgan. J. The Biology of Horror: Literature and Film. Board of Trustees, Southern Illinois University: USA, 2002.

Richard. D. Introduction to Film Studies. Edited by John Hill. Oxford: Oxford UP, 1998.

Snodgrass. M. Encyclopaedia of gothic literature. United States of America, 2005.

"What is Gothic fiction?" Horror.org. Horror Writers Association. Retrieved from http://www.horror.org/horror-is.htm, 2 Novem ber 2012 .

"What is horror fiction?" Horrordatabase.wordpress.com. Retrieved from http:/horrordata base.wordpress.com/2010/03/30/whatis-horror-fiction/, 8 November 2012

"Wordpress Presentation about Tim Burton". Retrieved from http://animationbegins.wordpress.com/2012/03/02/presenta tion-about-tim-burton/, 8 January 2012. 